\title{
Historical fires in Douglas-fir dominated riparian forests of the southern Cascades, Oregon
}

\author{
Diana L. Olson ${ }^{1}$ and James K. Agee ${ }^{2}$ \\ ${ }^{1}$ USDA Forest Service, Pacific Wildland Fire Sciences Laboratory; 400 N. $34^{\text {th }}$ St., Suite 201, \\ Seattle, WA 98103; 206-732-7844 (desk), 206-732-7801 (fax); dlolson@fs.fed.us \\ ${ }^{2}$ University of Washington, College of Forest Resources; Box 352100, Seattle, WA 98195; 206- \\ 543-2688 (desk), 206-543-3254 (fax); jagee@u.washington.edu
}

\begin{abstract}
Despite the ecological importance of fire in Pacific Northwest forests, its role in riparian forests is just beginning to be documented. This study reconstructed the historical occurrence of fire within riparian forests along different stream sizes in coast Douglas-fir (Pseudotsuga menziesii var. menziesii [Mirbel] Franco) dominated forests within the drier western hemlock (Tsuga heterophylla [Raf.] Sarg.) forest series of the Upper Steamboat Creek watershed of the Umpqua National Forest, Oregon. Fire dates were determined from a total of 194 firescarred wedges from stumps sampled at 15 riparian and 13 upslope one-hectare plots. Fire was common historically in both the riparian zones and upslope forests of this study area. Riparian Weibull median probability fire return intervals (WMPIs) were somewhat longer (ranging from 35-39 years, with fire return intervals ranging from 4-167 years) than upslope WMPIs (ranging from 27-36 years, with fire return intervals ranging from 2-110 years), but these differences were not significant. Fires were probably mixed in severity and likely patchy, considering the high incidence of fires occurring only at a riparian plot or only at an upslope plot within a pair, but not at both. Finally, fire return intervals showed a non-significant trend of decreasing length from west to east to north aspects. An increased sampling effort may have shown this decrease to be significant. Based on the results from this study, it is evident that restoring fire will be necessary to protect riparian forest health in this study area. Historical recruitment of large woody debris was likely patchy and pulsed for these mixed-severity fire regime forests.
\end{abstract}

Keywords: dendrochronology, Douglas-fir, fire history, fire scars, Oregon, Pseudotsuga menziesii, riparian forests, Tsuga heterophylla, Umpqua National Forest, western hemlock 


\section{INTRODUCTION}

Riparian zones are the interfaces between terrestrial and freshwater ecosystems (Gregory et al. 1991; Naiman and Decamps 1997) and they include an unusually diverse mosaic of landforms, biotic communities and physical environments relative to the rest of the landscape (Naiman et al. 1998). Management of riparian forests has become a primary concern in the Pacific Northwest (FEMAT 1993; USDA and USDI 1994; Sedell et al. 1997; USDA and USDI 1998; USDI et al. 1999) with a focus on maintaining and restoring riparian forests as late successional species refugia and as salmonid habitat.

Riparian zones have been granted certain levels of protection from the impacts of timber harvest and other forest management, with the hope of maintaining some degree of ecological integrity. Depending on the size of the river or stream, whether it supports fish, and its ownership, levels of protection range from none to retaining large buffer strips with limited or no management (FEMAT 1993; USDA and USDI 1994; Sedell et al. 1997; USDI et al. 1999). Broad goals of riparian forest protection measures include protecting streams from temperature extremes and erosion, providing organic input consumed by both aquatic vertebrates and invertebrates, and providing sources of large woody debris necessary for structural and functional diversity within the streams. Goals also include reducing the impact of human activities on fish, amphibian and aquatic invertebrate habitat within and along the streams, maintenance of plant and animal species refugia, and preservation of terrestrial and avian wildlife corridors.

This focus on riparian forests has raised questions about the ecological and physical processes associated with riparian zones and the impacts of current and historical management activities within and upslope of them (Agee 1988; Beschta 1990; Elmore et al.
1994; Wissmar et al. 1994; Fetherston et al. 1995; Kauffman et al. 1995; Naiman and Decamps 1997; Rieman and Clayton 1997; Benda et al. 1998; McClain et al. 1998; Gresswell 1999; Bisson et al. 2003; Dwire and Kauffman 2003). Such activities range from livestock grazing and timber production to the restoration of pre-Euroamerican settlement conditions. In order for protection measures to succeed, and in order to restore healthy ecological processes in degraded riparian forests, it is necessary to understand how riparian forest ecosystems function. Naiman et al. (1993) suggest that ecologically diverse riparian corridors are maintained by an active natural disturbance regime operating over a wide range of spatial and temporal scales. One such disturbance is fire.

Natural disturbances play an integral role in shaping forest ecosystems (White and Pickett 1985; Swanson et al. 1988; Sprugel 1991; Benda et al. 1998). Nearly every forest type in the Pacific Northwest has experienced a fire during the past millennium, with fire occurrences ranging from frequent to extremely infrequent (estimates of mean fire return intervals, e.g., the amount of time between successive fires, range from $<10$ years to $>900$ years; Agee 1993). Forests can be classified into low-, mixed- and highseverity historical fire regimes (Agee 1993). A forest with a low-severity fire regime will encounter more frequent fires with less fireinduced mortality than a forest with a highseverity fire regime. In the Pacific Northwest, low-severity fire regime forests historically included drier forests dominated by Oregon white oak (Quercus garryana Dougl. ex Hook.) woodland, ponderosa pine (Pinus ponderosa var. ponderosa P.\& C. Lawson) or mixed conifers. Mixed-severity fire regime forests included more mesic forests, such as mixed-evergreen, dry Douglas-fir (Pseudotsuga menziesii [Mirbel] Franco) and red fir (Abies magnifica A. Murr.) dominated forests. Mixed-severity fire regime forests 
experienced a mixture of stand replacing fires (i.e., high-severity), thinning fires (partial canopy mortality) and light surface fires of low severity. High-severity fire regime forests experienced infrequent, stand replacing fires and are typically cool, moist forests such as western hemlock (Tsuga heterophylla [Raf.] Sarg.)/coast Douglas-fir (Pseudotsuga menziesii var. menziesii [Mirbel] Franco) and Pacific silver fir (Abies amabilis [Dougl. ex Loud.] Dougl. ex Forbes) forests, along with subalpine forests. During the previous century and a half, Euroamerican activities in the Pacific Northwest have produced unprecedented fuel loads and forest structures conducive to high-severity fires within forests that historically experienced low- and mixedseverity fire regimes (Barrett 1988; Schwantes 1989; Agee 1993; Langston 1995; Agee 1996, 1998; Arno et al. 1997; Pyne 1997; Arno and Bunnell 2001)

Riparian zones typically extend higher elevation plant series into lower elevations of a watershed (Crowe and Clausnitzer 1997). In addition to transporting water, these zones act as cold air drainages at night and receive less insolation during the day compared to neighboring upslope forests. The combined effects of higher moisture inputs and lower evaporation make the riparian forest environment cooler and moister than associated upslope forests (Brosofske et al. 1997; Naiman et al. 1998; Williamson 1999). Consequently, riparian zones are frequently dominated by vegetation requiring higher levels of moisture than neighboring upslope forest. Often this vegetation is more structurally complex than in corresponding upslope forests, with greater basal areas, tree densities and canopy foliage weight (Williamson 1999), and a higher proportion of multi-layered canopy (and sub-canopy) structure. Locally, species with higher moisture requirements tend to have both thinner bark and retain lower branches such that girdling from fire or torching of the foliage is likely (Flint 1925). In other areas of the region, riparian shrubs and herbs have higher foliar moisture than uplands, but riparian conifer foliar moisture is similar to that of the same species growing in the uplands (Agee et al. 2002). The greater complexity in vegetative structure relative to upslope forests, combined with a lowered resistance to fire, theoretically results in more severe fire effects for vegetation in riparian forests compared to upslope forests.

Fire intensities are also assumed to vary between riparian and upslope forests. As a consequence of topography and increased moisture input, riparian zones should retain moisture longer into the summer dry season. Moister conditions reduce flammability and subsequently reduce chances of fire ignition. Therefore, riparian zones should have a reduced flammability compared to corresponding upslope forests. Also, fire ignition location influences initial fire behavior within a stand. Lightning is one of the primary sources of forest fire ignitions in the Pacific Northwest. Topographically, the upper one-third of hill slopes experience more lightning strikes than the lower two-thirds. Slope position affects initial fire behavior since fires starting at the top of a slope are more likely to be dominated by backing and flanking fire behavior, while those starting at the bottom of the slope are more likely to be dominated by heading fire (Agee 1993; Pyne et al. 1996). Heading fires typically have a higher intensity and a higher rate of spread than backing fires. A common fire scenario is that a fire ignites from a lightning strike in the upper portion of a slope, burns to the ridge in a heading fire but does not necessarily back down the slope at the same rate or intensity, and then perhaps is extinguished once it reaches a zone of moister vegetation. Occasionally, the channeling effect of wind along headwater riparian areas can intensify fires within those areas (Agee 1994). 
Historically, riparian forests likely experienced different fire regimes than nearby upslope forests (Heinselman 1973; Agee 1994; Camp et al. 1997) within a given landscape. The combined effects of topographical differences and higher moisture input, and the subsequent differences in vegetative communities, have been assumed to reduce fire frequency, vary fire intensity, and increase fire severity in riparian forests (Minnich 1977).

Most fire history studies have focused on upslope forest fire frequency, with only a few focusing on the fire regimes of riparian forests. In dry grand fir (Abies grandis var. grandis [Dougl. ex D. Don] Lindl.) forest series (ponderosa pine dominated) of northeast Oregon that historically experienced lowseverity fire regimes, Olson (2000) found riparian fire return intervals to be similar to those of upslope forest sites in two watersheds. However, for dry Douglas-fir forests in eastern Washington, Everett et al. (2003) found longer fire-free intervals in riparian forests relative to adjacent sideslope forests. In mixed-conifer forests of northern California, Skinner (1997) found riparian fire return intervals to be roughly twice as long as the upslope forest fire return interval. In subalpine fir (Abies lasiocarpa var. lasiocarpa [Hook.] Nutt.) forests of eastern Washington, Camp et al. (1997) found riparian areas have a higher probability of being "fire refugia," or areas that burn less frequently than the adjacent landscape. While riparian fires may be infrequent in some landscapes, they can be quite intense when they do occur (Agee 1998; Williamson 1999).

\section{Study Objectives}

The conversion of historically low- and mixed-severity fire regime forests to highseverity fire regimes, combined with concerns about the protection and restoration of riparian zones within these forests, requires a greater understanding of the historical role of fire within riparian zones. The objectives of this study were: 1) to determine whether historical fire frequencies differed between riparian and corresponding upslope forests, and 2) if they differed, to determine whether fire frequency differences varied by stream size. The study was limited to comparing fire frequencies between riparian and upslope forests through the use of fire scars, restricting the comparison to fires that had a non-lethal component.

\section{Study Area}

The study area is located in the Upper Steamboat Creek watershed (Figure 1) of the Umpqua National Forest, a tributary of the North Umpqua River on the western slope of the southern Cascades, approximately 60-70 kilometers northeast of Roseburg, Oregon. Annual precipitation ranges from 120 to 200 centimeters, falling primarily between October and June. Winter temperatures average between -4 and $4^{\circ} \mathrm{C}$, and July maximum temperatures average between 18 and $32^{\circ} \mathrm{C}$ (USDA 1997). Convective lightning storms are common during the summer and fall in the southern Oregon Cascades, and the Upper Steamboat Creek watershed is located within the zone having 3-4 lightning storms annually per 40,000 hectares (Morris 1934). Elevations range from 560 meters to 1,800 meters, and landforms within the watershed are the result of a deeply weathered volcanic landscape subjected to regional uplift over the past several million years. Slopes average 71 percent, and streams are characterized by generally steep-gradient bedrock and colluvial-constrained stream channels (USDA 1997). The watershed has an elevational gradient of plant associations, ranging from the coast Douglas-fir forest series to the dry western hemlock forest series to the Pacific silver fir forest series. The latter two series are near the southern limit of their ranges (Atzet et al. 1996). Study plots were located 
Fire Ecology, 1(1), 2005

(c) 2005 by the Association for Fire Ecology

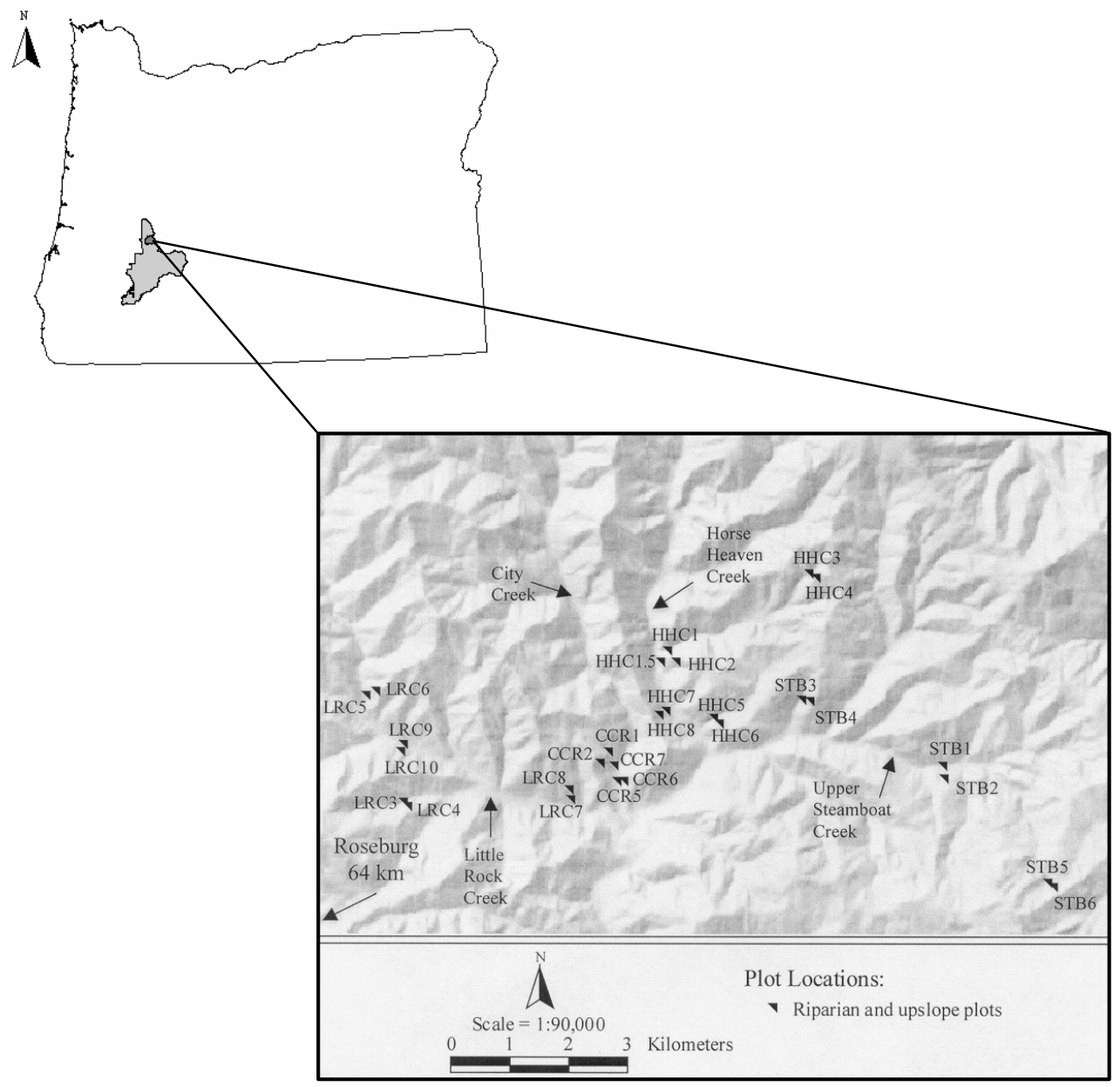

Figure 1. Location of the study area and the fire history plots within the Upper Steamboat Creek Watershed of the Umpqua National Forest, Oregon. 
within an approximately 6,500 hectare area of the lower elevations of the watershed (roughly one half the total area of the watershed).

Historical fire frequencies vary along latitudinal, longitudinal and elevational gradients in the region. To the north of the study area, historical fire frequencies tended to be longer than 100 years (Means 1982; Teensma 1987; Morrison and Swanson 1990; Garza 1995; Weisberg 1998). In these studies, lower elevation western hemlock plant associations generally had shorter fire frequencies than those in the Pacific silver fir series. Historical fire frequencies were less than 100 years for eastern Coast Range forests west of the study area (Impara 1997), but longer than 100 years in the Little River watershed (Van Norman 1998), just southwest of the Upper Steamboat Creek watershed. Farther south and southwest (in the Siskiyous, the Klamath Mountains, and the Southern Cascades), historical fire frequencies ranged from 8 to 161 years for coast Douglas-fir series and from 12 to 82 years for white fir series (Agee 1991a; Wills and Stuart 1994; Taylor and Skinner 1998, 2003; Stuart and Salazar 2000, Beaty and Taylor 2001).

\section{METHODS}

Fire scars were collected from plots located within riparian zones along small and large sized streams distributed throughout the study area. Each plot covered an area no larger than one hectare, and no plot edges spanned more than 100 meters. By keeping the plot size small, a point fire frequency could be interpreted from the data, in contrast to an area frequency (Agee 1993). Theoretically, a single point on the landscape should be represented by a single tree. However, not every fire scars every tree, so when sampling fire scars, collecting samples from more than one tree within each sampling plot provides a more complete record of fires for that "point" on the landscape. Because fire frequencies decrease as sample unit size increases (Arno and Petersen 1983), it is important that the plot size is minimal in area, yet still captures the history of fires at that location.

The definition of riparian zone used for this project includes the riparian zone of influence. The riparian zone of influence is the transition area between the riparian zone and upslope forest, identified by a change in plant composition, containing trees that may provide shade or contribute fine or large woody material to a stream (Raedeke 1988). This can be measured in terms of site potential tree lengths from either the edge of the stream channel, or, if applicable, the topographic edge of the floodplain. A site potential tree length (SPTL) represents the height of "a tree that has attained the average maximum height possible given site conditions where it occurs" (FEMAT 1993), which, for the purpose of this study, was 50 meters based on the Northwest Forest Plan Riparian Reserve requirements (FEMAT 1993). Reserve requirements include retaining a forest buffer with a width equivalent to two SPTLs from each side of a fish-bearing stream. Along non-fish-bearing streams and intermittent streams, buffer widths ranging from one half to one SPTL (roughly 15 to 50 meters) are required. The riparian zone definition for this study was based on these dimensions: for small streams, the riparian zone spanned 50 meters from either side of the stream or floodplain, while larger stream riparian zones included forest within 100 meters from the stream or floodplain.

Riparian plots were roughly divided between small streams and large streams and were located as close to the stream as possible. Originally, stream size was defined based on stream order, with small streams including $1^{\text {st }}$ and $2^{\text {nd }}$ order streams, and large streams including $3^{\text {rd }}$ and $4^{\text {th }}$ order streams. Stream ordering was based on Brown (1985) and determined from 7.5' USGS quadrangle maps. 
However, because categorizing streams according to stream order is no longer a standard approach to stream classification (S. Bolton, University of Washington, Seattle, pers. comm.), bankfull widths were measured for each stream. The bankfull width was defined as the width of the stream beyond which water flows onto the floodplain at roughly 1.5-year intervals. The floodplain was defined as the flat depositional surface adjacent to the stream. Within this study area, the larger order streams had bankfull widths greater than six meters, and the smaller order streams had bankfull widths less than six meters. Therefore, large streams were defined as streams having bankfull widths greater than six meters and small streams were defined as streams having bankfull widths less than six meters.

The primary species available for fire-scar sampling was coast Douglas-fir, which typically heals over fire scars when fire return intervals are sufficiently long, making them difficult or impossible to detect in a live tree (Taylor and Skinner 1998). This necessitated sampling in clearcuts, where evidence of fire scarring was observable on the stump surfaces. Additionally, plot selection was limited to recent cuts (less than 20 years old, where the stumps had not experienced too much rot) that extended into the riparian zone. Fifteen riparian plots were paired with upslope plots, totaling 28 plots (at two locations, two riparian plots from different sized streams were paired with a single upslope plot, referred to as a "trio" later) (Figure 1). Upslope plots were located outside of the riparian zone, at least 110 meters from the stream.

Within each plot the plant association (based on potential vegetation; Atzet et al. 1996), aspect and slope were determined; elevation and latitude/longitude readings were made using a Garmin GPS unit and verified on 7.5' USGS quadrangle maps (Table 1). For each riparian plot, the stream channel morphology was described based on classifications in Montgomery and Buffington (1993), and bankfull and floodplain widths were averaged from three measurements taken 20 meters apart.

Scarring on the surface of a stump was considered a fire scar if rings in the crosssection showed the classical curling, or if there were large (or multiple small), pitchy splits or break points along a ring that coincided with a fire date on a nearby sample. Presence of suppression or release (abrupt increases or decreases in radial growth) events that coincided with a nearby fire date, numerous resin ducts within a ring that coincided with the year following a nearby fire date, or the rare presence of charring along a ring, were also considered evidence of fire. However, fire evidence other than the classical curling scar required corroboration from other, nearby samples. Based on this conservative determination of fire evidence, it is possible that the amount of fire scarring was underestimated within the samples collected.

Within each plot, three to 10 fire-scarred partial cross-sections were removed from stumps using a chainsaw, following methods described by Arno and Sneck (1977). Crosssections were selected based on their quality: well-preserved, clearly distinguishable scars were sampled when they could be safely removed from the stump. For each crosssection collected, the species, height of scar, and scar position relative to topography were recorded, and a diagram drawn relating it spatially to other samples and topographic features at that plot.

A total of 194 cross-sections (280 individual fire scars) were collected during the summers of 1997 and 1998. Each crosssection was sanded until individual cells were discernible (400 grit). Cross-sections were then crossdated against a tree-ring chronology developed for this study, allowing each fire scar to be associated with a specific year. Of the 194 cross-sections collected, 187 (96\%) 
Fire Ecology, 1(1), 2005

(C) 2005 by the Association for Fire Ecology

Table 1. Riparian plots and stream characteristics (bold) and characteristics of their paired upslope plots. Plant codes are defined at the bottom of the table.

\begin{tabular}{|c|c|c|c|c|c|c|c|c|c|c|}
\hline $\begin{array}{c}\text { Plot } \\
\text { ID } \\
\end{array}$ & $\begin{array}{c}\text { Plant } \\
\text { Association } \\
\end{array}$ & $\begin{array}{c}\text { Elevation } \\
(\mathrm{m})\end{array}$ & $\begin{array}{c}\text { Aspect } \\
\text { (degree) }\end{array}$ & $\begin{array}{c}\text { Slope } \\
\text { (degree) }\end{array}$ & $\begin{array}{c}\text { Longitude } \\
\text { (degree) }\end{array}$ & $\begin{array}{l}\text { Latitude } \\
\text { (degree) }\end{array}$ & $\begin{array}{c}\text { Stream } \\
\text { Order } \\
\end{array}$ & $\begin{array}{c}\text { Stream } \\
\text { Description }\end{array}$ & $\begin{array}{c}\text { Bankfull } \\
\text { Width (m) }\end{array}$ & $\begin{array}{l}\text { Floodplain } \\
\text { Width (m) }\end{array}$ \\
\hline HHC1 & Tshe/Acci-Gash-SWO & 700 & 298 & 40 & -122.593 & 43.527 & 2 & step-pool & 3.3 & 6.1 \\
\hline HHC1.5 & Tshe/Gash-Rhma3-SWO & 670 & 278 & 42 & -122.594 & 43.526 & 3 & step-pool & 8.1 & 10.6 \\
\hline $\mathrm{HHC} 2$ & Psme/Arne-SWO & 790 & 260 & 36 & -122.592 & 43.526 & -- & -- & -- & -- \\
\hline HHC3 & Tshe/Acci-Rhma3 & 980 & 349 & 26 & -122.563 & 43.540 & 1 & colluvial & 0.6 & 4.2 \\
\hline $\mathrm{HHC} 4$ & Tshe/Acci-Rhma3 & 1030 & 336 & 25 & -122.563 & 43.540 & -- & -- & -- & -- \\
\hline HHC5 & Thpl/Bene2/Pomu & 680 & $\mathbf{0}$ & 34 & -122.578 & 43.517 & 1 & step-pool & 2.6 & 7.1 \\
\hline HHC6 & Tshe/Gash-Rhma3-SWO & 730 & 334 & 42 & -122.576 & 43.517 & -- & -- & -- & -- \\
\hline HHC7 & Tshe-Thpl/Rhma3 & 640 & 64 & 28 & -122.599 & 43.518 & 3 & step-pool & 9.1 & 12.3 \\
\hline HHC8 & Tshe/Gash-Rhma3-SWO & 700 & 64 & 38 & -122.600 & 43.518 & -- & -- & -- & -- \\
\hline CCR1 & Psme/Acci-Bene2 & 740 & 53 & 41 & -122.604 & 43.510 & $\mathbf{1}$ & bedrock & 2.0 & 3.2 \\
\hline $\mathrm{CCR} 2$ & Psme/Gash-Rhma3 & 800 & 78 & 42 & -122.605 & 43.511 & -- & -- & -- & -- \\
\hline CCR7 & Tshe/Gash-Pomu-SWO & 630 & 95 & 35 & -122.601 & 43.508 & 3 & step-pool & 11.6 & 14.1 \\
\hline CCR5 & Tshe/Gash-Rhma3-SWO & 610 & 240 & 25 & -122.598 & 43.506 & 3 & step-pool & 10.7 & 14.1 \\
\hline CCR6 & Psme/Acci-Bene2 & 670 & 232 & 30 & -122.597 & 43.506 & -- & -- & -- & -- \\
\hline LRC3 & Tshe-Thpl/Rhma3 & 720 & 356 & 35 & -122.636 & 43.501 & $\mathbf{1}$ & step-pool & 2.2 & 3.6 \\
\hline LRC4 & Tshe/Rhma3-Gash-SWO & 780 & 354 & 22 & -122.643 & 43.500 & -- & - & -- & -- \\
\hline LRC5 & Tshe/Gash-Rhma3-SWO & 720 & 272 & 35 & -122.654 & 43.516 & 3 & step-pool & 8.8 & 10.7 \\
\hline LRC6 & Tshe-Cach6/Gash-Rhma3 & 800 & 286 & 40 & -122.653 & 43.516 & -- & - & -- & -- \\
\hline LRC7 & Psme/Acci-Bene2 & 610 & 194 & 35 & -122.611 & 43.503 & 4 & step-pool & 12.1 & 18.2 \\
\hline LRC8 & Psme/Acci-Bene2 & 670 & 204 & 30 & -122.611 & 43.504 & -- & - & -- & -- \\
\hline LRC9 & Tshe-Thpl/Rhma3 & 670 & 40 & 8 & -122.636 & 43.509 & 4 & step-pool & 11.6 & 11.8 \\
\hline LRC10 & Tshe-Cach6/Gash-Rhma3 & 740 & 24 & 45 & -122.645 & 43.508 & -- & -- & -- & -- \\
\hline STB1 & Tshe/Gash-Rhma3-SWO & 760 & 343 & 37 & -122.524 & 43.512 & 3 & step-pool & 6.2 & 7.8 \\
\hline STB2 & Psme/Gash-Rhma3 & 850 & 343 & 26 & -122.523 & 43.511 & -- & -- & -- & -- \\
\hline STB3 & Tshe/Gash-Rhma3-SWO & 790 & 278 & 35 & -122.786 & 43.520 & $\mathbf{1}$ & bedrock & 0.8 & 1.7 \\
\hline STB4 & Psme/Acci-Bene2 & 890 & 278 & 32 & -122.785 & 43.520 & -- & -- & -- & -- \\
\hline STB5 & Tshe/Gash-Rhma3-SWO & 1180 & 339 & 38 & -122.509 & 43.496 & $\mathbf{0}$ & step-pool & 1.2 & 2.3 \\
\hline STB6 & Psme/Acci-Bene2 & 1240 & 319 & 28 & -122.507 & 43.496 & -- & - & -- & -- \\
\hline
\end{tabular}

Overstory:

Cach6 = Castanopsis chrysophylla (Doug1. ex Hook.) A. DC.

(accepted nomenclature: Chchc4 = Chrysolepis chrysophylla [Dougl. ex Hook.] Hjelmqvist var. chrysophylla)

Psme = Pseudotsuga menziesii var. menziesii (Mirbel) Franco

Tshe $=$ Tsuga heterophylla (Raf.) Sarg.

Thpl = Thuja plicata Donn ex D. Don

Understory:

Acci $=$ Acer circinatum Pursh

Arne $=$ Arctostaphylos nevadensis Gray

Bene2 = Berberis nervosa Pursh

(accepted nomenclature: Mane2 $=$ Mahonia nervosa (Pursh) Nutt.)

Gash $=$ Gaultheria shallon Pursh

Rhma3 = Rhododendron macrophyllum D. Don ex G. Don

SWO $=$ southwest Oregon 
were successfully crossdated. Generally, dates could be determined based on visual crossdating, using a binocular microscope. However, for those samples where visual crossdating was too difficult, ring widths were measured and input into a crossdating software program (COFECHA; Holmes 1983). In addition to fire date determination, the use of a microscope allowed an approximate determination of the season of a fire's occurrence, depending on the scar location within the tree ring record, either in the earlywood, latewood, or at the boundary of the latewood and the following year's earlywood.

The tree-ring chronology used for this study was developed using standard methodology (Stokes and Smiley 1968; Fritts 1976), and was derived from 12 coast Douglas-firs and two sugar pines (Pinus lambertiana Dougl.) located along ridgetops within the Upper Steamboat Creek watershed. The pattern of ring widths within the 341-year chronology was comparable to a coast Douglas-fir chronology developed by Graumlich (1983) for the Abbot Creek Research Natural Area, located approximately 70 kilometers to the south.

\section{Data Analysis}

The time period used in this study was 1650-1900. This period was chosen in order to get a fire record length that was long enough to be able to characterize historical fire frequency, but not so long that the sample depth was compromised. The early constraint of this time period (1650) was based on more than 60 percent of the plots having at least one sample with a tree ring record extending throughout the time period. Previous studies have utilized time periods when 30 percent of the plots had fire records during the entire time period (Heyerdahl et al. 2001) or when 25 percent of the plots had at least one tree with a tree ring record extending back to the beginning of the selected time period (Wright and Agee 2004). The choice of 1900 as the cutoff year was made to avoid having the fire record impacted by Euroamerican settlement and subsequent land use practices (specifically, fire exclusion).

Data were summarized for each plot category (e.g., riparian plots vs. upslope plots, small stream riparian plots vs. large stream riparian plots, etc.) by calculating fire return intervals at each plot then analyzing intervals according to plot category. Typically, fire history studies provide composite fire return interval calculations for each plot (Wills and Stuart 1994; Heyerdahl 1997; Impara 1997; Taylor and Skinner 1998; Van Norman 1998; Weisberg 1998; Stuart and Salazar 2000). Fire years derived from all of the samples in one plot are combined into a master fire chronology of fire dates for that plot. Plot fire return intervals are then determined by calculating the period of time between each of the fires. The fire history software program FHX2 (Grissino-Mayer 1995) produces mean and median fire return intervals (based on both a normal distribution and a Weibull distribution), calculates confidence intervals based on a Weibull distribution, and shows how well the data fit both the normal and Weibull distributions. The Weibull distribution is frequently used in fire history studies because it is a flexible distribution that allows fire return interval distributions, typically skewed to the right, to be represented mathematically. The Weibull median probability fire return interval (WMPI) provides a least biased measure of central tendency in skewed distributions of fire return interval data (Grissino-Mayer 1995).

The resulting calculations represent fire return intervals from a plot. The mean, median or WMPI calculated for each of the plots are then typically used as replicates within each plot category. However, because the FHX2 program requires at least four fires (i.e., three fire return intervals) for each plot in 
order to calculate Weibull parameters, and only 12 of 28 plots in this study recorded four or more fires, an alternative analysis method was used. All of the individual fire return intervals (rather than fire dates) calculated for each plot (rather than the mean, median or WMPI) were pooled with fire return intervals from other plots within the same category, then compared to pooled fire return intervals from other categories. With this type of analysis method, the fire return intervals are still representative of a point fire frequency rather than an area frequency.

\section{Statistical Analyses}

Plot-based fire return interval statistics based on both the normal distribution and the Weibull distribution were produced using the statistical function of the FHX2 fire history software. Other parametric and nonparametric statistics were performed using the Statistix for Windows statistical software package (Analytical Software 1998).

For each plot in this study, the following descriptive statistics were calculated: the number of fires recorded per plot, and the minimum and maximum fire return intervals. Whenever possible, the WMPI, the Weibull $80 \%$ confidence interval (the $10^{\text {th }}$ percentile fire return interval subtracted from the $90^{\text {th }}$ percentile fire return interval), and the mean, median, standard deviation, and the coefficient of variation based on the normal distribution were calculated. For each category of plots (e.g., riparian, small stream upslope, etc.), the minimum and maximum fire return intervals were calculated, as well as the mean and median fire return intervals (based on the normal distribution), the WMPI, and the $80 \%$ confidence interval.

Once the fire scar data were summarized, the data were tested for normality using the Wilk-Shapiro procedure. Because the data typically did not fit the normal distribution, categories were compared using the equivalent nonparametric tests: the Wilcoxon signed rank test, the Mann-Whitney U-test for unmatched samples, and the Kruskal-Wallis one-way analysis of variance. In addition to testing whether the fire return interval data fit a normal distribution, the data were tested for fit along a Weibull distribution. For the fire return intervals calculated at each plot, the FHX2 fire history software calculated a Kolmogorov-Smirnov d-statistic in order to determine the goodness-of-fit of the fire return interval distribution from that plot to both a normal distribution and a Weibull distribution. Similarly, for each category of fire return intervals, a Chi-square statistic was calculated to determine the goodness-of-fit of the fire return interval data to a Weibull distribution. For this study, an alpha value of 0.05 was used to determine statistical significance.

Fire return interval comparisons were made between riparian and upslope forests, riparian and upslope forests according to stream size, small and large stream riparian forests, and aspects. The aspect analyses were performed because variations had been found in nearby study areas (Impara 1997; Taylor and Skinner 1998, 2003; Van Norman 1998; Weisberg 1998, Beaty and Taylor 2001). First, comparisons were made according to aspect alone, i.e., fire return intervals were not differentiated by riparian versus upslope locations. Then riparian and upslope plots were compared according to aspect. North aspects were defined as the range from $316^{\circ}$ to $45^{\circ}$, east aspects from $46^{\circ}$ to $135^{\circ}$, south aspects from $136^{\circ}$ to $225^{\circ}$, and west aspects from $226^{\circ}$ to $315^{\circ}$.

\section{RESULTS}

The master fire chronology for riparian and upslope plots sampled in this study area indicates a sporadic yet frequent occurrence of fires during the 1650-1900 time period (Figure 2). Although sampling was not designed to determine the extents of individual fires, the 
Figure 2. Master fire chronology for the riparian and upslope plots in the Upper Steamboat watershed. The time period used in this study was 1650-1900 (the non-grayed portion of the figure). The riparian plots are highlighted in blue.

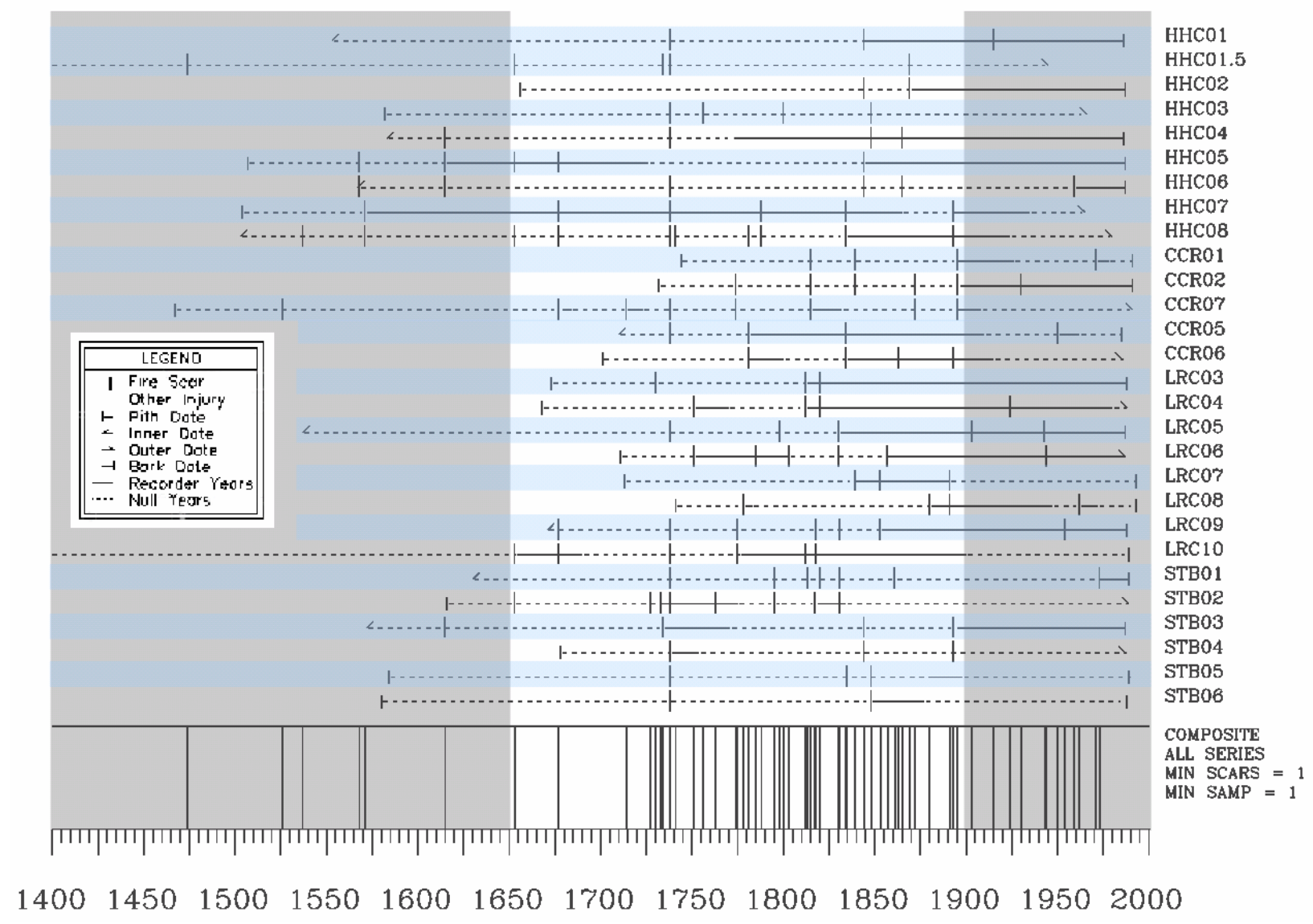


lack of correspondence among fire dates across sample sites suggests that most fires were small relative to the study area.

\section{Stream Size Comparisons}

Fire return intervals in riparian forests were slightly longer but not statistically different from fire return intervals in upslope forests, and this was consistent for plots along both large and small streams (Figure 3). When fire return intervals from both large and small streams were pooled, riparian fire return intervals were statistically similar to upslope fire return intervals (38 year and 29 year WMPIs, with fire return intervals ranging from 4-167 years and 2-110 years, respectively; $\mathrm{p}=0.15$, two-tailed MannWhitney U-Test for unmatched samples) and they had similarly wide confidence intervals (Figure 3). There was no significant difference between large stream riparian fire return intervals and their corresponding upslope fire return intervals (35 year and 27 year WMPIs, with fire return intervals ranging from 4-131 years and 3-102 years, respectively; $\mathrm{p}=0.13$, two-tailed MannWhitney U-Test for unmatched samples), or between small stream riparian fire return intervals and their corresponding upslope fire return intervals (39 year and 36 year WMPIs, with fire return intervals ranging from 8-167 years and 8-110 years, respectively; $p=0.80$, two-tailed Mann-Whitney U-Test for unmatched samples). Additionally, there was no statistical difference between large stream riparian fire return intervals and small stream riparian fire return intervals (35 year and 39 year WMPIs, with fire return intervals ranging from 4-131 years and 8-167 years, respectively; $\mathrm{p}=0.27$, two-tailed MannWhitney U-Test for unmatched samples). Confidence intervals for small stream riparian fire return intervals and their corresponding upslope fire return intervals were similar in width, yet were wider than the confidence intervals for large riparian fire return intervals and corresponding upslope fire return intervals.

\section{Aspect Comparisons}

Fire return intervals did not differ by aspect, either when fire return intervals from riparian and upslope plots were combined (Figure 4) or compared separately (Figure 5). Although fire return intervals gradually decreased from west to east to north aspects, there were no significant differences between the fire return intervals (45 year, 36 year and 27 year WMPIs, with fire return intervals ranging from 4-131 years, 3-61 years, and 5167 years, respectively; $\mathrm{p}=0.34$, KruskalWallis one-way nonparametric analysis of variance). There were too few fire return intervals from south aspects to include them in the analysis (only one riparian plot and one upslope plot were located on south-facing slopes).

When the aspects were differentiated by riparian and upslope fire return intervals (Figure 5), no statistical differences were present $(\mathrm{p}=0.46$, Kruskal-Wallis one-way nonparametric analysis of variance) except when the west aspect riparian fire return intervals were compared to the west aspect upslope fire return intervals. West aspect riparian fire return intervals were longer than their upslope counterparts (56 year vs. 30 year WMPIs, with fire return intervals ranging from 4-131 years and 18-106 years, respectively; $\mathrm{p}=0.02$, one-tailed MannWhitney U-Test for unmatched samples) and the Weibull $80 \%$ confidence interval for west aspect riparian fire return intervals was considerably wider than the confidence interval for west aspect upslope fire return intervals. 


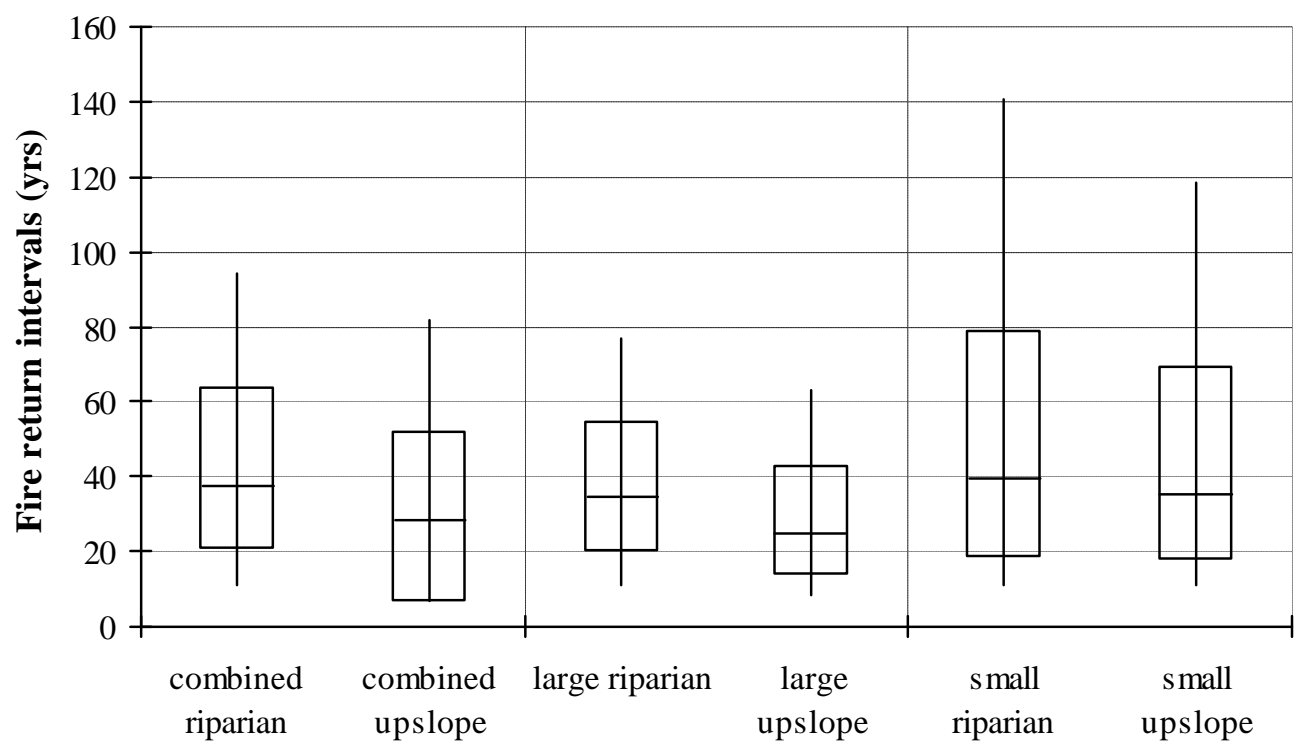

Figure 3. Fire return interval ranges for combined riparian and combined upslope plot categories, large stream riparian and upslope plot categories, and small stream riparian and upslope plot categories. Box plots represent, from top to bottom: 90th percentile and 75th percentile exceedance levels, WMPI, 25th percentile and 10th percentile exceedance levels (all percentiles were calculated from the Weibull distribution).

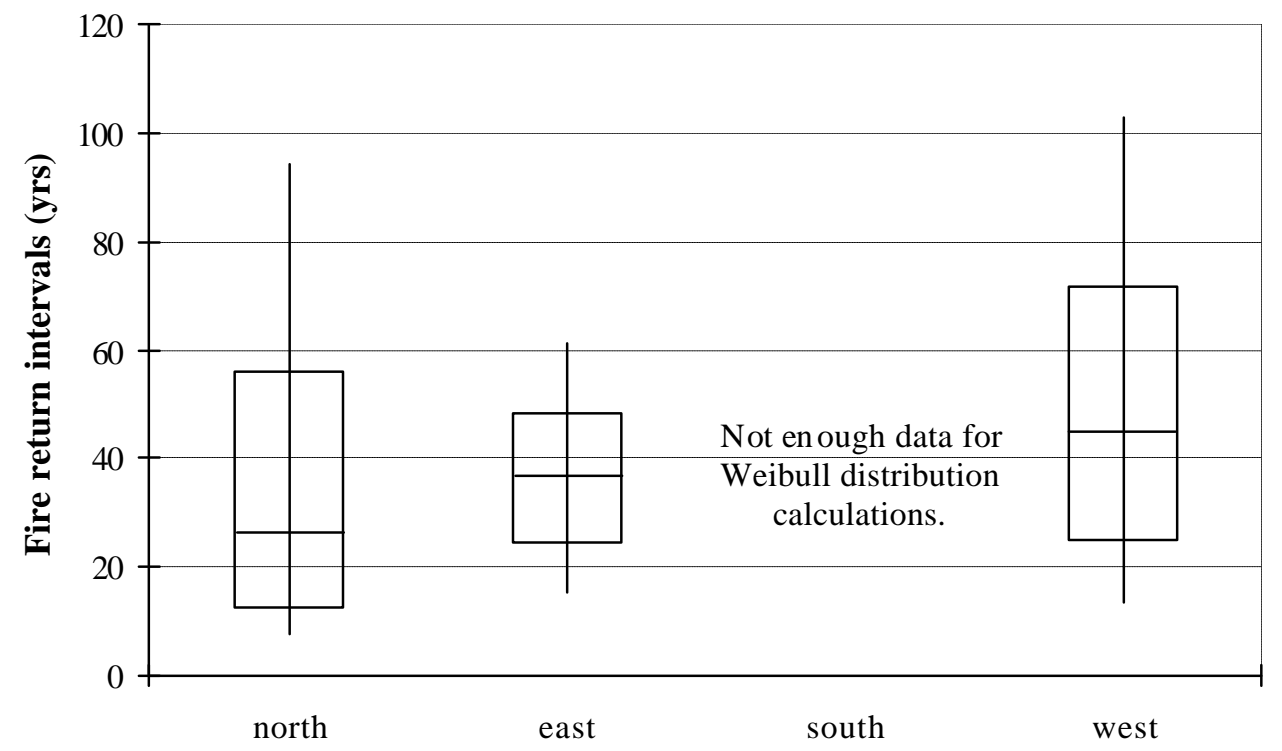

Figure 4. Fire return interval ranges for combined riparian and upslope fïre return intervals from north, east, south and west aspects. Box plots represent, from top to bottom: 90th percentile and 75 th percentile exceedance levels, WMPI, 25th percentile and 10th percentile exceedance levels (all percentiles were calculated from the Weibull distribution). There were not enough fire return intervals in the south aspect fire return interval category to determine a WMPI or confidence intervals. 


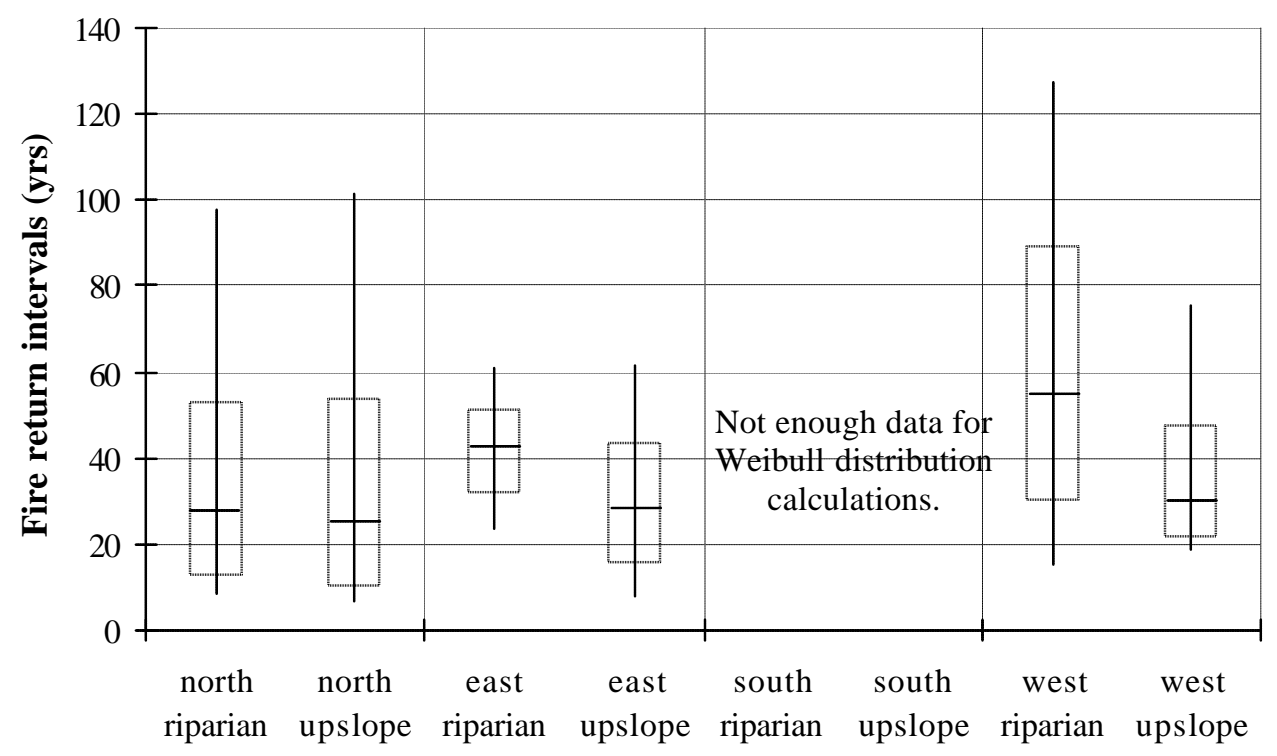

Figure 5. Fire return interval ranges for riparian and upslope fire return intervals from north, east, south and west aspects. Box plots represent, from top to bottom: 90th percentile and 75th percentile exceedance levels, WMPI, 25th percentile and 10th percentile exceedance levels (all percentiles were calculated from the Weibull distribution). There were not enough fire return intervals in the south aspect riparian and upslope fire return interval categories to determine WMPIs or confidence intervals.

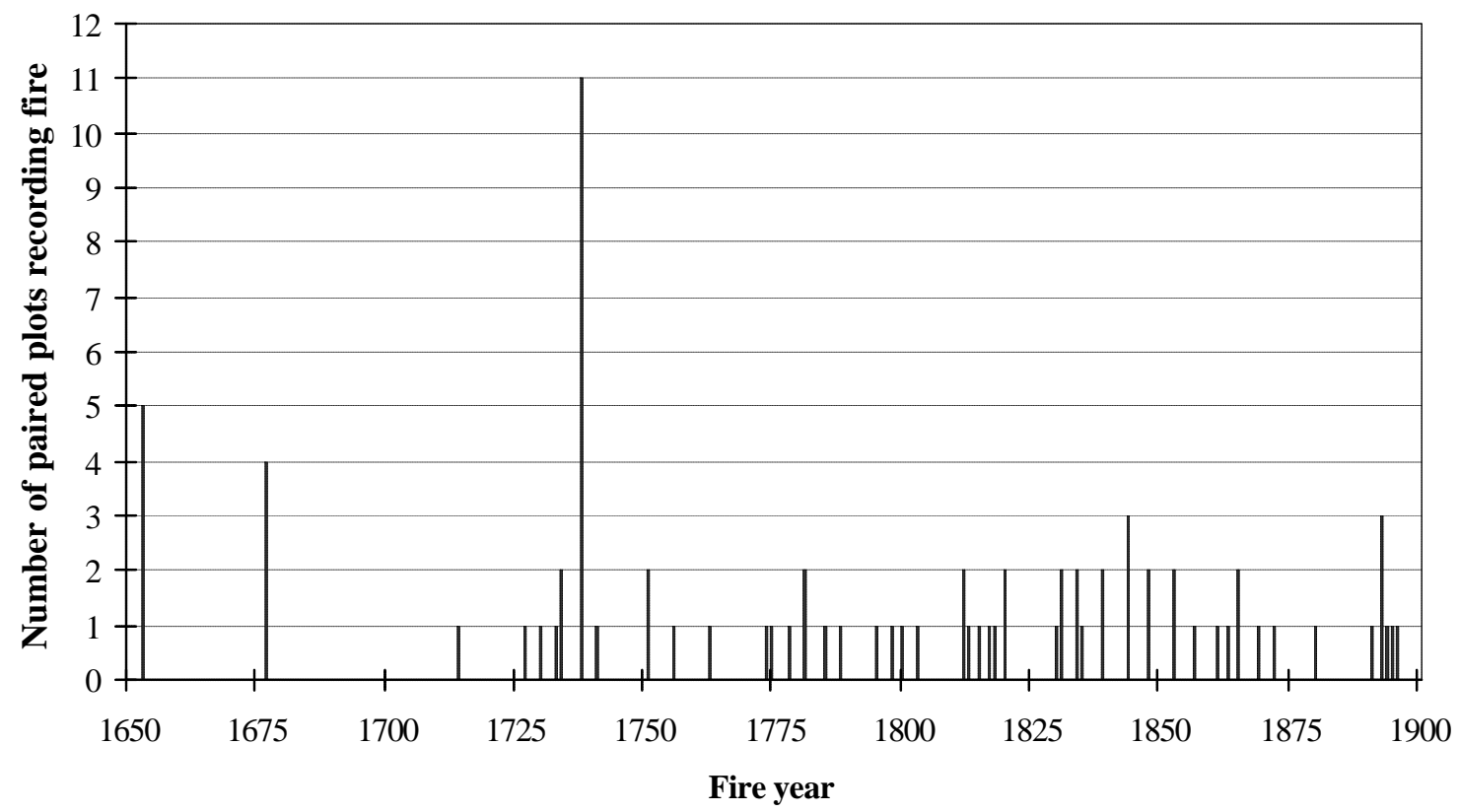

Figure 6. Number of paired plots (combined riparian and upslope plots) recording each fire year between 1650 and 1900 . 


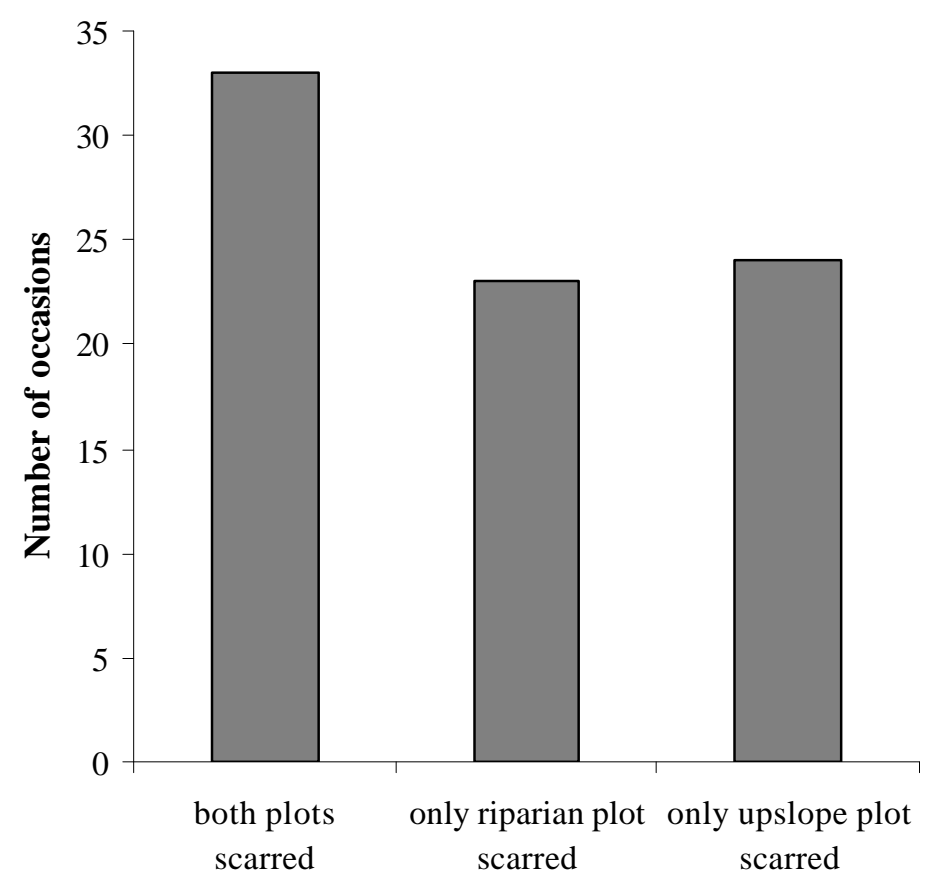

Figure 7. Number of occasions when a fire scarred both the riparian plot and the upslope plot within a pair of plots, compared to the number of occasions when a fire scarred only the riparian plot or only the upslope plot within a pair.

\section{Fire Year Comparisons}

Although this study was not designed to determine the spatial extents of historical fires (i.e., it was not sampled in a grid pattern), some of the spatial attributes of the historical fires can be inferred. Since the riparian and upslope plots were located in pairs (and in two cases, trios), landscape scale spatial characteristics of fires were examined in terms of the pairs of plots, rather than individual plots. Most fire years did not show evidence of burning much of the study area, as they were recorded only in one pair of plots (32 out of the 48 fires occurring between 1650 and 1900, Figure 6). However, 11 fire years included two pairs of plots, and there were individual fire years where three (1844 and 1893), four (1677), five (1653) and 11 (1738) pairs of plots burned at some point during the year. The longest distance between plots pairs recording the same fire year was 12 kilometers (1738). Five other fire years were recorded at plot pairs at least five kilometers apart (1653, 1677, 1820, 1831 and 1848), and nine other fire years were recorded at plot pairs at least one kilometer apart $(1734,1751,1781,1834$, 1839, 1844, 1853, 1865 and 1893). Additionally, one fire year outside of the 1650-1900 time period may have been spatially extensive (1615, with three plot pairs burning roughly three kilometers apart).

Another analysis compared whether, during a given year, fire scars were recorded in both the riparian and upslope plots of a riparian/upslope pair (or trio). Most fires burned only one plot within a pair (Figure 7). There were 48 fire years recorded for this study area between 1650 and 1900. These 48 fire years were recorded on a total of 80 occasions within the 13 pairs of riparian and upslope plots. On 33 of the 80 occasions, fire was recorded in both the riparian and upslope plots within a pair, while on 23 occasions fire was recorded only in the riparian plot, and on 
24 occasions fire was recorded only in the upslope plot.

\section{DISCUSSION}

Fires in the Upper Steamboat Creek watershed were relatively frequent for the coast Douglas-fir dominated western hemlock forest series, and the watershed is representative of the drier end of a forest type that has over an order of magnitude of variation in fire return intervals (Agee 1991b). Fire return intervals in this study area were shorter than fire frequencies determined by Means (1982), Teensma (1987), Morrison and Swanson (1990), Garza (1995), Impara (1997), Van Norman (1998), and Weisberg (1998) for western Oregon Cascades forests to the north and Oregon Coast Range forests to the west. These other studies found average fire frequencies ranging between 73 years and 246 years for forests within the western hemlock and Pacific silver fir zones. Furthermore, the average fire return intervals found in this study area tended to be longer than those found by Wills and Stuart (1994), Skinner (1997), Taylor and Skinner (1998, 2003), and Beaty and Taylor (2001) south of this study area, in coast Douglas-fir and white fir forests of the Klamath Mountains and Southern Cascades of California. Fire frequencies in these studies were found to average between 8 and 54 years. The range of median fire return intervals in this study area were more comparable to the range of fire frequencies found for mid-elevation forests of the Siskiyou Mountains of southwestern Oregon (16 to 64 years; Agee 1991a). They were also comparable to the range of median fire intervals found in white fir forests of the coastal mountains of northwestern California (12-161 years, Stuart and Salazar 2000).

Most fires appeared to be relatively small in size, and may reflect similar patchiness in fire size to that found in mixed-severity fire regimes in red fir forests to the south (van
Wagtendonk 1995; Chappell and Agee 1996). Weisberg and Swanson (2003) summarized fire history studies in the Washington and Oregon Cascades, and determined there was considerable evidence supporting two periods of widespread fire, one roughly between the early 1400s and 1650, and the other roughly between 1800 and the early 1900s, with a period of reduced area burned roughly between 1650 and 1800. The three fire years in this study that appear to be the largest (1653, 1677 and 1738; each of these fires burned within four or more pairs of plots, with at least two of the pairs more than five kilometers apart) all fall within Weisberg and Swanson's period of reduced area burned.

Fire return intervals were found to be statistically similar between riparian and upslope forests along large streams, between riparian and upslope forests along small streams, and between riparian forests along large and small streams. The fact that the confidence intervals for small stream riparian and upslope fire return intervals were wider than those for large stream riparian and upslope fire return intervals suggests that the variability in fire return intervals may be more meaningful than a mean or median, and that distance from a stream may be less influential than location in the upper versus lower regions of a drainage. Historically, larger streams in the Cascades tended to be travel corridors for Native American populations, and the use of fire by early humans was substantial in these forest types (Boyd 1999). Although the sources of any of the historic fires were not possible to ascertain, the reduced variability in fire occurrence along larger streams may represent a Native American influence (e.g., Barrett and Arno 1982).

A possible reason for the similarity between riparian and upslope fire return interval lengths was the definition of a riparian zone. Riparian plot locations tended to represent the outer portion of the riparian zone and are likely comparable to the lower regions 
of what other researchers have termed "lower slope positions" (Impara 1997; Weisberg 1998). The upslope plot locations may not have, in reality, experienced conditions different enough from the riparian plot locations to change the fire regime. No samples were collected immediately adjacent to large streams due to buffers left at the time of cutting, therefore most of the samples were 30 meters or more from large streams, even though they were within the managerial boundary of a riparian zone. Samples were available in closer proximity to the small streams, since buffers were typically smaller or non-existent along these streams. The functional riparian zone (in terms of vegetation, moisture gradients, etc.) may be narrower than what was used in this study.

Within other mixed-severity fire regimes in the region, fire severity appears to vary between aspects, and also between ridgetops and lower slope positions. In one Klamath Mountains study area, Taylor and Skinner (1998) found that average fire return intervals on south and west aspects were shorter than on north and east aspects, and that the upper slopes and ridgetops and intermediate south and west aspects appeared to experience larger patches of higher severity fires relative to lower slopes and east and north aspects. Similarly, Weisberg (1998) found that north aspects in the Blue River watershed experienced lower severity fires than other aspects, and lower slope positions experienced lower severity fires than upper slope positions. In a different area of the Klamath Mountains, Taylor and Skinner (2003) found median fire return intervals significantly decreased from north to south to west to east. Impara (1997) found both severity and frequency were higher for the upper slope positions.

In this study, aspect had no statistically significant effect on fire return interval. Within a given aspect quadrant, the only significant difference was that west aspect riparian fire return intervals were longer and had a wider confidence interval than west aspect upslope fire return intervals. There was a non-significant trend of decreasing fire return intervals from west to east to north aspects (Figure 4). There were too few fire return intervals from south aspect plots to include in the analysis. The fewer fire return intervals on south and west aspects may be an artifact of sampling, as the presence of fire scars in recent clearcuts was necessary for the analyses, and these clearcuts were not evenly distributed by aspect. If the trend of differences between aspects in this study area was in fact a real one, then it was nearly opposite to the trends found in the Klamath Mountains. Perhaps moister conditions on north and east aspects caused fire intensity to be lower within these areas (leaving more live, fire-scarred trees, rather than killing the trees and subsequently erasing the record), and perhaps the drier conditions found on west aspects were dry enough that fires were of higher intensity and, consequently, higher severity (leaving fewer live, fire-scarred trees). Or conversely, perhaps fires on these dry west aspects were of low enough intensity that they didn't scar the trees.

\section{CONCLUSIONS}

Fire was a common occurrence in these riparian forests. Additionally, fire return intervals within the operational definition of a riparian zone were similar to those in adjacent upslope forests. If a goal of forest management is to restore forests to historical conditions, then it will be necessary to reintroduce fire to riparian forests. If a goal is to maintain these forests in their current condition, it is important to recognize the role that fire played in determining the structure and vegetational composition within these forests.

Understandably, reintroducing fire to riparian forests must be carefully considered when there are threatened and endangered 
species within the streams or streamside forests. In a synthesis of literature about fire and aquatic ecosystems, Gresswell (1999) concluded that salmonid species have evolved strategies to survive disturbances occurring at the frequency of historical fires, but that local populations may have been ephemeral in time and space. At present, long term detrimental effects of high-severity fires are generally limited to areas where native populations have either declined or become isolated due to human influences. Although fire was common in riparian forests within the study area, it may be necessary to totally protect some of these streamside forests until more habitat is available. Many historical riparian fires were likely a result of upslope fires backing down into the riparian zone. Subsequently, if upslope forests are treated for fuels reduction, either with prescribed fire or other silvicultural treatments, then perhaps a wildfire ignited within the upslope forests would be less likely to gain the intensity needed to burn within the moister portion of the riparian zone.

In terms of coarse woody debris recruitment within these riparian forests, and the subsequent addition of large woody debris to the streams, it is likely that periodic inputs mirrored historical fire frequencies (Agee 2002). In this study area, fire return intervals were variable in length, and the mixedseverity fires likely included at least patches of higher severity fire (and, subsequently, a high degree of tree mortality). Large woody debris creation adjacent to streams would probably have occurred patchily and in pulses in the riparian forests of this study area.

\section{ACKNOWLEDGEMENTS}

Funding for this project was provided by Mark Huff and Jim Sedell through cooperative agreements between the USDA Forest Service, Pacific Northwest Research Station and the University of Washington College of Forest Resources. Logistical, GIS, field and laboratory support was provided by Debbie Anderson, Barbara Fontaine, Ray Davis, Phil Hurvitz, Kelley Jorgensen, Tina Brown, Alan and Kathryn Olson, Nathan Williamson, Brita Pyfer, and Spencer Toepfer. Technical advice was provided by Susan Bolton, Linda Brubaker, Emily Heyerdahl, Clint Wright, and an anonymous reviewer. We greatly appreciate all of their help. 


\section{REFERENCES}

Agee, J.K. 1988. Successional dynamics in forest riparian zones. In: Streamside Management: Riparian Wildlife and Forestry Interactions. Proceedings of a Symposium on Riparian Wildlife Interactions, 11-13 Feb. 1987, ed. K.J. Raedeke, 31-44. Seattle: University of Washington.

Agee, J.K. 1991a. Fire history along an elevational gradient in the Siskiyou Mountains, Oregon, USA. Northwest Science 65:188-199.

Agee, J.K. 1991b. Fire history of Douglas-fir forests in the Pacific Northwest. In: Wildlife and Vegetation of Unmanaged Douglas-Fir Forests, tech. ed. L.F. Ruggiero, K.B. Aubry, A.B. Carey, M.H. Huff, 25-33. Portland: USDA Forest Service General Technical Report PNW-GTR-285.

Agee, J.K. 1993. Fire Ecology of Pacific Northwest Forests. Washington, DC: Island Press.

Agee, J.K. 1994. Fire and Weather Disturbances in Terrestrial Ecosystems of the Eastern Cascades. Portland: USDA Forest Service General Technical Report PNW-GTR-320.

Agee, J.K. 1996. Fire in the Blue Mountains: a history, ecology and research agenda. In: Search for a Solution: Sustaining the Land, People, and Economy of the Blue Mountains, ed. R.G. Jaindl and T.M. Quigley, 119-145. Washington, DC: American Forests in cooperation with the Blue Mountains Natural Resources Institute.

Agee, J.K. 1998. The landscape ecology of western forest fire regimes. Northwest Science 72:2434.

Agee, J.K. 2002. Fire as a coarse filter for snags and logs. In: Proceedings of the Symposium on the Ecology and Management of Dead Wood in Western Forests, 1999 Nov. 2-4, Reno, NV, tech. coord. W.F. Laudenslayer, Jr., P.J. Shea, B.E. Valentine, C.P. Weatherspoon, T.E. Lisle, 359-368. Albany: USDA Forest Service General Technical Report PSWGTR-181.

Agee, J.K., C.S. Wright, N. Williamson, and M.H. Huff. 2002. Foliar moisture content of Pacific Northwest vegetation and its relation to wildland fire behavior. Forest Ecology and Management 167: 57-66.

Analytical Software. 1998. Statistix for Windows Statistical Software. Tallahassee: Analytical Software.

Arno, S.F. and T.D. Petersen. 1983. Variation in Estimates of Fire Intervals: A Closer Look at Fire History on the Bitterroot National Forest. Ogden: USDA Forest Service Research Paper RP-INT-301. 
Arno, S.F., H.Y. Smith, and M.A. Krebs. 1997. Old Growth Ponderosa Pine and Western Larch Stand Structures: Influences of Pre-1900 Fires and Fire Exclusion. Ogden: USDA Forest Service Research Paper RP-INT-495.

Arno, S.F. and K.M. Sneck. 1977. A Method for Determining Fire History in Coniferous Forests of the Mountain West. Ogden: USDA Forest Service General Technical Report GTRINT-42.

Arno, S.F. and S. Bunnell. 2001. Flames in Our Forest. Washington, DC: Island Press.

Atzet, T., D.E. White, L.A. McCrimmon, P.A. Martinez, P.R. Fong, and V.D. Randall. 1996. Field Guide to the Forested Plant Associations of Southwestern Oregon. Portland: USDA Forest Service Technical Paper R6-NR-ECOL-TP-17-96.

Barrett, S.W. 1988. Fire suppression's effects on forest succession within a central Idaho wilderness. Western Journal of Applied Forestry 3:76-80.

Barrett, S.W. and S.F. Arno. 1982. Indian fires as an ecological influence in the northern Rockies. Journal of Forestry 80:647-651.

Beaty, R.M. and A.H. Taylor. 2001. Spatial and temporal variation of fire regimes in a mixed conifer forest landscape, Southern Cascades, California, USA. Journal of Biogeography 28:955-966.

Benda, L.E., D.J. Miller, T. Dunne, G.H. Reeves, and J.K. Agee. 1998. Dynamic landscape systems. In: River Ecology and Management: Lessons from the Pacific Coastal Ecoregion, ed. R.J. Naiman and R.E. Bilby, 261-288. New York: Springer-Verlag Inc.

Beschta, R.L. 1990. Effects of fire on water quantity and quality. In: Natural and Prescribed Fire in Pacific Northwest Forests, ed. J.D. Walstad, S.R. Radosevich, and D.V. Sandberg, 219-232. Corvallis: Oregon State University Press.

Bisson, P.A., B.E. Rieman, C. Luce, P.F. Hessburg, D.C. Lee, J.L. Kershner, G.H. Reeves, and R.E. Gresswell. 2003. Fire and aquatic ecosystems of the western USA: current knowledge and key questions. Forest Ecology and Management 178:213-229.

Boyd, R., ed. 1999. Indians, Fire and the Land in the Pacific Northwest. Corvallis: Oregon State University Press.

Brosofske, K.D., J. Chen, R.J. Naiman, and J.F. Franklin. 1997. Harvesting effects on microclimatic gradients from small streams to uplands in western Washington. Ecological Applications 7:1188-1200.

Brown, E.R., tech. ed. 1985. Management of Wildlife and Fish Habitats in Forests of Western Oregon and Washington. Washington, DC: USDA Forest Service, U.S. Government Printing Office Publication Number R6-F\&WL-192-1985. 
Camp, A., C. Oliver, P. Hessburg, and R. Everett. 1997. Predicting late-successional fire refugia predating European settlement in the Wenatchee Mountains. Forest Ecology and Management 95:63-77.

Chappell, C.B. and J.K. Agee. 1996. Fire severity and tree seedling establishment in Abies magnifica forests, southern Cascades, Oregon. Ecological Applications 6:628-640.

Crowe, E.A. and R.R. Clausnitzer. 1997. Mid-Montane Wetland Plant Associations of the Malheur, Umatilla and Wallowa-Whitman National Forests. Portland: USDA Forest Service, Technical Paper R6-NR-ECOL-TP-22-97.

Dwire, K.A. and J.B. Kauffman. 2003. Fire and riparian ecosystems in landscapes of the western USA. Forest Ecology and Management 178:61-74.

Elmore, D.W., B.L. Kovalchik, and L.D. Jurs. 1994. Restoration of riparian ecosystems. In: Volume IV: Restoration of Stressed Sites and Processes. Eastside Forest Ecosystem Health Assessment, compiled by R.L. Everett, 87-92. Portland: USDA Forest Service General Technical Report PNW-GTR-330.

Everett, R., R. Schellhaus, P. Ohlson, D. Spurbeck, and D. Keenum. 2003. Continuity in fire disturbance between riparian and adjacent sideslope Douglas-fir forests. Forest Ecology and Management 175:31-47.

FEMAT (Forest Ecosystem Management Assessment Team). 1993. Forest Ecosystem Management: An Ecological, Economic, and Social Assessment. Report of the Forest Ecosystem Management Team, July 1993: USDA, Forest Service; USDC, National Marine Fisheries Service; USDI, Bureau of Land Management, Fish and Wildlife Service, and National Park Service; Environmental Protection Agency. Portland: U.S. Government Printing Office.

Fetherston, K.L., R.J. Naiman, and R.E. Bilby. 1995. Large woody debris, physical process, and riparian forest development in montane river networks of the Pacific Northwest. Geomorphology 13:133-144.

Flint, H.R. 1925. Fire resistance of northern Rocky Mountain conifers. Idaho Forester 7(7): 7$10,41-43$.

Fritts, H.C. 1976. Tree Rings and Climate. New York: Academic Press.

Garza, E.S. 1995. Fire history and fire regimes of East Humbug and Scorpion Creeks and their relation to the range of Pinus lambertiana Dougl. M.F. thesis, Oregon State University.

Graumlich, L. 1983. Tree-Ring Data, Colorado, New Mexico and Oregon. International TreeRing Data Bank. IGBP PAGES/World Data Center - A for Paleoclimatology. 
Contribution Series \#83-029. Boulder: National Oceanic and Atmospheric Administration/National Geophysical Data Center Paleoclimatology Program.

Gregory, S.V., F.J. Swanson, W.A. McKee, and K.W. Cummins. 1991. An ecosystem perspective of riparian zones: focus on links between land and water. BioScience 41:540551.

Gresswell, R.E. 1999. Fire and aquatic ecosystems in forested biomes of North America. Transactions of the American Fisheries Society 128:193-221.

Grissino-Mayer, H.D. 1995. Tree-ring reconstructions of climate and fire history at El Malpais National Monument, New Mexico. Ph.D. dissertation, University of Arizona.

Heinselman, M.L. 1973. Fire in the virgin forests of the Boundary Waters Canoe Area, Minnesota. Quarternary Research 3:329-382.

Heyerdahl, E.K. 1997. Spatial and temporal variation in historical fire regimes of the Blue Mountains, Oregon and Washington: the influence of climate. Ph.D. dissertation, University of Washington.

Heyerdahl, E.K., L.B. Brubaker, and J.K. Agee. 2001. Spatial controls of historical fire regimes: a multiscale example from the Interior West, USA. Ecology 82:660-678.

Holmes, R.L. 1983. Computer-assisted quality control in tree-ring dating and measurement. Tree-Ring Bulletin 43:69-78.

Impara, P.C. 1997. Spatial and temporal patterns of fire in the forests of the central Oregon Coast Range. Ph.D. dissertation, Oregon State University.

Langston, N. 1995. Forest Dreams, Forest Nightmares: The Paradox of Old Growth in the Inland West. Seattle: University of Washington Press.

Kauffman, J.B., R.L. Case, D. Lytjen, N. Otting, and D.L. Cummings. 1995. Ecological approaches to riparian restoration in northeast Oregon. Restoration and Management Notes 13:12-15.

McClain, M.E., R.E. Bilby, and F.J. Triska. 1998. Nutrient cycles and responses to disturbance. In: River Ecology and Management: Lessons from the Pacific Coastal Ecoregion, ed. R.J. Naiman and R.E. Bilby, 347-372. New York: Springer-Verlag, Inc.

Means, J.E. 1982. Developmental history of dry coniferous forests in the central western Cascade Range of Oregon. In: Forest Succession and Stand Development Research in the Northwest, ed. J.E. Means, 142-158. Corvallis: Forest Research Laboratory, Oregon State University. 
Minnich, R.A. 1977. The geography of fire and big-cone Douglas-fir, Coulter pine, and western conifer forest in the east Transverse Ranges, southern California. In: Proceedings on the Environmental Consequences of Fire and Fuel Management in Mediterranean Ecosystems, ed. H.A. Mooney and C.E. Conrad, 443-450. Washington, DC: USDA Forest Service General Technical Report WO-3.

Montgomery, D.R. and J.M. Buffington. 1993. Channel Classification, Prediction of Channel Response, and Assessment of Channel Condition. Report TFW-SH10-93-002 prepared for the SHAMW committee of the Washington State Timber/Fish/Wildlife Agreement, 24 June 1993. Seattle: University of Washington.

Morris, W.G. 1934. Lightning Storms and Fires on the National Forests of Oregon and Washington. USDA Forest Service, Pacific Northwest Experiment Station.

Morrison, P.H. and F.J. Swanson. 1990. Fire History and Pattern in a Cascade Range Landscape. Portland: USDA Forest Service General Technical Report PNW-GTR-254.

Naiman, R.J. and H. Decamps. 1997. The ecology of interfaces: riparian zones. Annual Review of Ecology and Systematics 28:621-658.

Naiman, R.J., H. Decamps, and M. Pollock. 1993. The role of riparian corridors in maintaining regional biodiversity. Ecological Applications 3:209-212.

Naiman, R.J., K.L. Fetherston, S.J. McKay, and J. Chen. 1998. Riparian forests. In: River Ecology and Management: Lessons from the Pacific Coastal Ecoregion, ed. R.J. Naiman and R.E. Bilby, 289-323. New York: Springer-Verlag, Inc.

Olson, D.L. 2000. Fire in riparian zones: a comparison of historical fire occurrence in riparian and upslope forests in the Blue Mountains and southern Cascades of Oregon. M.S. thesis, University of Washington.

Pyne, S.J. 1997. Fire in America: A Cultural History of Wildland and Rural Fire. Seattle: University of Washington Press.

Pyne, S.J., P.L. Andrews and R.D. Laven. 1996. Introduction to Wildland Fire. $2^{\text {nd }}$ ed. New York: John Wiley and Sons, Inc.

Raedeke, K.J. 1988. Introduction. In: Streamside Management: Riparian Wildlife and Forestry Interactions. Proceedings of a Symposium on Riparian Wildlife Interactions, 11-13 Feb. 1987, ed. K.J. Raedeke, xiii - xvi. Seattle: University of Washington.

Rieman, B. and J. Clayton. 1997. Wildfire and native fish: issues of forest health and conservation of sensitive species. Fisheries 22:6-15.

Schwantes, C.A. 1989. The Pacific Northwest: an Interpretive History. Lincoln: University of Nebraska Press. 
Sedell, J.R., D.C. Lee, B.E. Rieman, R.F. Thurow, and J.E. Williams. 1997. Effects of proposed alternatives on aquatic habitats and native fishes. In: Evaluation of the EIS Alternatives by the Science Integration Team, Volume I, ed. T.M. Quigley, K.M. Lee, and S.J. Arbelbide, 435-528. Portland: USDA Forest Service, Pacific Northwest Research Station.

Skinner, C.N. 1997. Fire history in riparian reserves of the Klamath Mountains. In: Proceedings - Fire in California Ecosystems: Integrating Ecology, Prevention, and Management, Nov. 17-20, 1997, San Diego, California, ed. S. Cooper and N. Sugihara. California Association for Fire Ecology (CAFE).

Sprugel, D.G. 1991. Disturbance, equilibrium, and environmental variability: what is "natural" vegetation in a changing environment? Biological Conservation 58:1-18.

Stokes, M.A. and T.L. Smiley. 1968. An Introduction to Tree-Ring Dating. Tucson: University of Arizona Press.

Stuart, J.D. and L.A. Salazar. 2000. Fire history of white fir forests in the coastal mountains of northwestern California. Northwest Science 74:280-285.

Swanson, F.J., T.K. Kratz, N. Caine, and R.G. Woodmansee. 1988. Landform effects on ecosystem patterns and processes. BioScience 38:92-98.

Taylor, A.H. and C.N. Skinner. 1998. Fire history and landscape dynamics in a late-successional reserve, Klamath Mountains, California, USA. Forest Ecology and Management 111:285-301.

Taylor, A.H. and C.N. Skinner. 2003. Spatial patterns and controls on historical fire regimes and forest structures in the Klamath Mountains. Ecological Applications 13:704-719.

Teensma, P.D. 1987. Fire history and fire regimes of the central western Cascades of Oregon. Ph.D. dissertation, University of Oregon.

USDA (Forest Service). 1997. Upper Steamboat Creek Watershed Analysis. USDA Forest Service, Umpqua National Forest, North Umpqua Ranger District.

USDA (Forest Service) and USDI (Bureau of Land Management). 1994. Environmental Assessment for the Implementation of Interim Strategies for Managing Anadromous FishProducing Watersheds in Eastern Oregon and Washington, Idaho, and Portions of California (PACFISH). Washington, DC: USDA Forest Service and USDI Bureau of Land Management.

USDA (Forest Service) and USDI (Fish and Wildlife Service, Bureau of Land Management). 1998. South Cascades Late Successional Reserve Assessment. Portland. 
USDI (Fish and Wildlife Service), USDC (National Marine Fisheries Service), US Environmental Protection Agency, Washington State (Office of the Governor, Department of Natural Resources, Department of Fish and Wildlife, and Department of Ecology), Colville Confederated Tribes and other Washington State Tribes, Washington State Association of Counties, Washington Forest Protection Association and Washington Farm Forestry Association. 1999. Forests and Fish Report. A Report to the Forest Practices Board and the Governor's Salmon Recovery Office, February 1999.

Van Norman, K.J. 1998. Historical fire regimes of the Little River Watershed. M.S. thesis, Oregon State University.

van Wagtendonk, J.W. 1995. Large fires in wilderness areas. In: Proceedings: Symposium on Fire in Wilderness and Park Management, tech. coord. J.K. Brown, R.W. Mutch, C.W. Spoon, and R.H. Wakimoto, 113-116. USDA Forest Service Gen. Tech. Rep. INT-GTR320.

Weisberg, P.J. 1998. Fire history, fire regimes, and development of forest structure in the central western Oregon Cascades. Ph.D. dissertation, Oregon State University.

Weisberg, P.J. and F.J. Swanson. 2003. Regional synchroneity in fire regimes of western Oregon and Washington, USA. Forest Ecology and Management 172:17-28.

White, P.S. and S.T.A. Pickett. 1985. Natural disturbance and patch dynamics: an introduction. In: The Ecology of Natural Disturbance and Patch Dynamics, ed. S.T.A. Pickett and P.S. White, 3-13. New York: Academic Press, Inc.

Williamson, N.M. 1999. Crown fuel characteristics, stand structure, and fire hazard in riparian forests of the Blue Mountains, Oregon. M.S. thesis, University of Washington.

Wills, R.D. and J.D. Stuart. 1994. Fire history and stand development of a Douglas-fir/hardwood forest in northern California. Northwest Science 68:205-212.

Wissmar, R.C., J.E. Smith, B.A. McIntosh, H.W. Li, G.H. Reeves, and J.R. Sedell. 1994. Ecological health of river basins in forested regions of Eastern Washington and Oregon. In: Eastside Forest Ecosystem Health Assessment, Vol. III: Assessment, R.L. Everett, assessment team leader, ed. P.F. Hessburg. USDA Forest Service General Technical Report PNW-GTR-326.

Wright, C.S. and J.K. Agee. 2004. Fire and vegetation history in the eastern Cascade Mountains, Washington. Ecological Applications 14:443-459. 